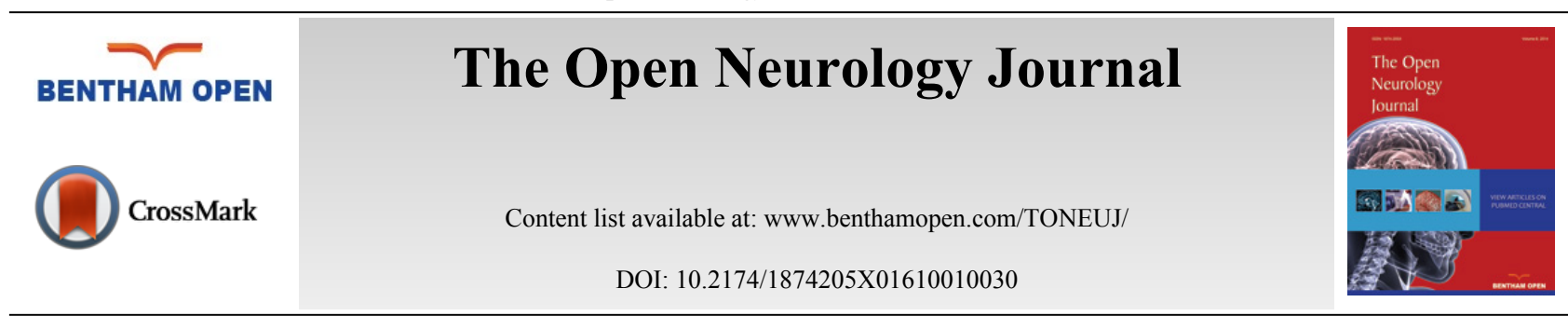

\title{
LETTER
}

\section{Child Abuse Syndrome (CAS): A Newly Recognized Distinct Entity}

\author{
Enrico Parano ${ }^{1, *}$, Xena Giada Pappalardo ${ }^{1}$, Piero Pavone ${ }^{2}$, Martino Ruggieri ${ }^{3}$ and Sebastiano \\ Cavallaro ${ }^{1}$ \\ ${ }^{1}$ Institute of Neurological Science, Functional Genomics Center, National Research Council (CNR), Catania, Italy \\ ${ }^{2}$ Unit of Pediatrics and Pediatric Emergency "C. Gravina", University Hospital "Policlinico-Vittorio Emanuele", \\ Catania, Italy \\ ${ }^{3}$ Department of Clinical and Experimental Medicine, Section of Pediatrics and Child Neuropsychiatry, University of \\ Catania, Italy
}

A number of children and adolescents experience stressful events during their life spans, which can affect them both physically and emotionally. Their reactions to these events are usually time-limited, as most of these children recover without further problems. However, a child or an adolescent may experience a severe traumatic event, including situations where someone's life (especially parents' lives) is threatened or where major injuries occur (e.g., victims or witnesses of physical/sexual abuse or of violence in the home or community, of a car accident, a natural disaster or a war event, or the diagnosis of a life-threatening illness); in these cases, the risk of developing a Post Traumatic Stress Disorder (PTSD) becomes more likely, and is directly related to the severity of the trauma experienced, to the likelihood of the trauma being repeated, and, when the trauma affects a child's relative, also to the child's relationship with the victim $[1,2]$.

The American Academy of Child \& Adolescent Psychiatry (AACAP) has recently proved that PTSD related to sexual abuse in children can manifest itself with unique clinical patterns, including specific signs and symptoms of varying degrees of intensity: losing interest in activities which normally gave them joy or pleasure, a regression to thumb-sucking, bedwetting or other age-inappropriate behaviors, also including loss of talking skills. Other leading hallmarks are the tendency to repeat some forms of behavior previously perpetrated against themselves; the development of a strong attachment to a parent or toward another reference figure; the manifestation of unusual fears regarding early death; and severe concentration problems interfering with learning or social activities. Additional potential consequences in adult life include suicidal thinking, active engagement in suicidal behavior and the onset of addictive relationships to food, alcohol or drugs [3, 4].

During the last few years, increasing evidence of the changes in brain structure and function occurring in abused children suffering from PTSD have been recorded by neuroimaging (MRI, fMRI, PECT) and neurophysiological (EEG, ERP) studies on large cohorts, mainly including changes in the frontal-limbic networks, the hippocampus and the amygdala [5,6]. In addition, clinical and molecular geneticists have suggested and demonstrated that abused children who develop PTSD experience a biologically specific form of the disorder different from those caused by other types of trauma, including distinct genomic alterations and unique epigenetic DNA methylation profiles $[7,8]$.

According to this recent clinical, neuroimaging, neurophysiological, genomic and epigenetic evidence, independently reported by separate teams of researchers, we propose that, for a better and more accurate clinical and

\footnotetext{
* Address correspondence to this author at the Institute of Neurological Science, Functional Genomics Center, National Research Council (CNR), Catania, Italy; E-mail: enrico.parano@libero.it
} 
diagnostic evaluation and understanding of the clinical phenotype, the overall manifestations and symptoms caused by child abuse be regarded as a specific and distinct entity, grouped under the term of "Child Abuse Syndrome" (CAS).

\section{CONFLICT OF INTEREST}

The authors confirm that this article content has no conflict of interest.

\section{ACKNOWLEDGEMENTS}

Declared none.

\section{REFERENCES}

[1] Shaw JA. Children, adolescents and trauma. Psychiatr Q 2000; 71(3): 227-43. [http://dx.doi.org/10.1023/A:1004630127000] [PMID: 10934747]

[2] Cohen JA, Scheeringa MS. Post-traumatic stress disorder diagnosis in children: challenges and promises. Dialogues Clin Neurosci 2009; 11(1): 91-9. [PMID: 19432391]

[3] The Ranch on Piney River, Inc. "Child sexual abuse as a cause of PTDS (Post Traumatic Stress Disorder)", Feb. 27, 2013, [Online]. Available from: https:/www.recoveryranch.com/articles/trauma-and-ptsd-articles/child-sexual-abuse-as-a-cause-of-ptsd-post-traumatic-stress-disorder/

[4] Adams JA. Medical evaluation of suspected child sexual abuse: 2011 update journal of child sexual abuse. J Child Sex Abuse 2011; 20(5): 588-605.

[5] Hart H, Rubia K. Neuroimaging of child abuse: a critical review. Front Hum Neurosci 2012; 6: 52. [http://dx.doi.org/10.3389/fnhum.2012.00052] [PMID: 22457645]

[6] Tupler LA, De Bellis MD. Segmented hippocampal volume in children and adolescents with posttraumatic stress disorder. Biol Psychiatry 2006; 59(6): 523-9.

[http://dx.doi.org/10.1016/j.biopsych.2005.08.007] [PMID: 16199014]

[7] Mehta D, Klengel T, Conneely KN, et al. Childhood maltreatment is associated with distinct genomic and epigenetic profiles in posttraumatic stress disorder. Proc Natl Acad Sci USA 2013; 110(20): 8302-7. [http://dx.doi.org/10.1073/pnas.1217750110] [PMID: 23630272]

[8] Raabe FJ, Spengler D. Epigenetic Risk Factors in PTSD and Depression. Front Psychiatry 2013; 4: 80. [http://dx.doi.org/10.3389/fpsyt.2013.00080] [PMID: 23966957]

(C) Parano et al. Licensee Bentham Open.

This is an open access article licensed under the terms of the Creative Commons Attribution-Non-Commercial 4.0 International Public License (CC BY-NC 4.0) (https://creativecommons.org/licenses/by-nc/4.0/legalcode), which permits unrestricted, non-commercial use, distribution and reproduction in any medium, provided the work is properly cited. 